\title{
The Multiple Aspects Representations in The Hundred Secret Senses by Amy Tan
}

\author{
ZHANG Jie \\ China Youth University for Political Sciences, Beijing, China
}

\begin{abstract}
This paper is to analyze the novel in the following aspects: The Chinese-American cultural conflicts, the mother and daughter relations and sisters' relations, the psychological critics, and the postcolonial identity. The novel is about multiple explanations of the aspects mentioned above. The writer confuses the Chinese culture, the relationship of the two sisters. Under the superficial description, the writer shows the psychological status of the main character and the practically existence of postcolonial identity and embodiment in the novel.

Keywords: the hundred secret senses, culture, relationship, psychological status, postcolonial identity and embodiment
\end{abstract}

\section{Introduction of the Author}

Amy Tan is the author of The Joy Luck Club, The Kitchen God's Wife, and The Hundred Secret Senses (1995), other novels and two children's books. The Hundred Secret Senses is her third important novel. It is considered as another masterpiece. And essays and stories have appeared in numerous magazines and anthologies. Her work has been translated into more than 25 languages. Tan, who has a master's degree in linguistics from San Jose University, has worked as a language specialist to programs serving children with developmental disabilities. She lives with her husband in San Francisco and New York.

\section{The Introduction of the Novel}

The novel, The Hundred Secret Senses (1995), by Amy Tan, focuses on the relationship between Chinese-born Kwan and her younger, Chinese American sister Olivia, who serves as the book's primary narrator. Olivia and Kwan's relationship begins when their father dies and Kwan is sent to live with the family. Olivia is embarrassed by Kwan because she is unfamiliar with American customs and does not speak English well. She constantly makes a fool of herself, and Olivia is teased by peers for having a "retarded" sister.

The book starts off with Olivia describing her life as a child and how when her older sister, who she knew nothing about, comes to live with her and her family after her father dies. Olivia grows up never changing her thoughts towards Kwan. Finally, Olivia agrees to go to China with Kwan to find out more about her culture. There, Simon and Olivia fall in love again, but only after they get in a fight and Simon gets lost. While in desperation to find her husband, Olivia realizes how much she actually loves Kwan. Kwan never lets Olivia down; she is always the big sister she has wanted.

ZHANG Jie, associate professor, master, Department of Foreign Language and Literature, China Youth University for Political Sciences. 
Kwan makes Olivia come to see that besides what we understand through our five senses, there are many things that can only be understood by using the "hundred secret senses". This story is about the journey of identity, family history, past lives, and ultimately, love.

\section{The Critics From the Publications for the Book}

After the publication of the novel, it got appraisal from the publications. On the back cover of the book, readers can read:

The wisest and most captivating novel Tan has written. (The Boston Sunday Globe)

Truly magical...unforgettable...The first-person narrator is Olivia Laguni, and her unrelenting nemesis from childhood on is her half-sister, Kwan Li. ...It is Kwan's haunting predictions, her implementation of the secret senses, and her linking of the present with the past that cause this novel to shimmer with meaning — and to leave it in the reader's mind when the book has long been finished. (The San Diego Tribune)

Her most polished work... Tan is a wonderful storyteller, and the story's many strands-Olivia's childhood, her courtship and marriage, Kwan's ghost stories and village tales - propel the work to its climactic but bittersweet end. (USA Today)

Tan has once more produced a novel wonderfully like a hologram: turn it this way and find Chinese-Americans shopping and arguing in San Francisco; turn it that way and the Chinese of Changmian village in 1864 are fleeing into the hills to hide from the rampaging Manchus. ...The Hundred Senses doesn't simply return to a world but burrows more deeply into it, following new trails to fresh revelations. (Newsweek)

\section{The Chinese Culture Found Its Great Spaces in the Novel}

Culture is the most mentioned topic for Amy Tan's novels, for she was born into an immigrant family. She undoubtedly faced the conflicts of the parents' culture and the American culture she was growing up in. In the novel The Hundred Secret Senses, readers can read and sense the Chinese culture throughout the novel.

The novel begins with the story "the girl with Yin eyes". The Yin eye is a typical kind of saying in China, which is about a kind of superstition in Chinese culture. Those with the Yin eyes are considered to know either what happen in the actual world or what is supposed to happen in the other world-where the dead people live.

In the second story, she told a tradition of Chinese minority dating. It is vividly described:

During marriage - matching festivals, there boys would climb up to our high villages and our girls would sing the old mountain sounds that we had brought form the north a thousand years before. A boy had to sing back to the girl he wanted to marry, finding words to match her song. If his voice was soft, or his words were clumsy, too bad no marriage. That's why Hakka people are not only fiercely strong, they have good voices, and clever minds for winning whatever they want. (p. 34)

\section{There Are Many Chinese Symbols in the Novel}

For the oversea Chinese writers, they unavoidably write what have happened in China, and the Chinese ways of thinking. But they have different ways to express the Chinese symbols. Some writer may convert the Chinese idiom in English, but for Amy Tan, she usually uses the Chinese Pinyin instead.

In her novel, Amy Tan frequently uses Pinyin to express the idea: "retard means fantou" (p. 49), “Changmian means never-ending songs" (p. 43), “Geiwokan" (p. 56), "Hwai Dan”—bad egg (p. 148).

The writer lets the character use Chinese to note the identity and choices of her identity. 


\section{Some Chinese Philosophy in the Novel}

Amy Tan's novel was not only full of Chinese images and symbols; even the Chinese philosophy was embedded in the novel. She mentioned that how things mixed together produce another: Water and dirt make mud, heat and water make tea, foreigners and opium make trouble. The five tastes that give us the memories of life: sweet, sour, bitter, pungent, and salty.

And in the third chapter, two girls talked about the overview about the world, which is the importance of the human understanding the world. The novel mentioned: anger, respect, shame, hope, and stupidity. And the difference between hope and stupidity may result from the ways of thinking of Chinese and foreigners. Besides the last five senses to the world what they talked is "the American sense of importance that later causes troubles between us. Because her senses led to opinions, and her opinions to conclusions, and sometimes they were different from mine" (p. 55). It is the difference between Chinese way of thinking and American way of thinking. It is the life philosophy.

\section{Chinese History in the Novel}

In the novel, not only the culture of Chinese, the signs of Chinese and the particular Chinese history are also mentioned:

Libby —ah, this was 1948, when the Nationalists and Communists were fighting over China. (p. 178)

In those days Chinese money was worthless. It must be that this man had bought the papers for a lot of gold and bad favors. Did he betray secrets to the Naturalists? Did he sell the names of leaders in the People's Liberation Army. (p. 180)

Some of the description here is the real history of Chinese at that time. The Nationalists and communists were fighting to determine the fate of China.

And while the fighting between the Nationalists and the Communists China was short of salt. That is the reality. In this novel the author also mentioned the fact that salt is precious. "after he left, I want to cry for having spoiled my salt" (p. 190).

\section{Sisters' Relationship}

Mother and daughter relationship is another main focus of Amy Tan's story. In her most novels, Amy Tan illustrated the relations between mothers and daughters, but in The Hundred Secret Senses, she fully explained the sisters' relationship, besides the usual mother and daughter relationship. In this chapter the sisters' relationship will be discussed.

It is really a story of two sisters. Ellen wrote an article From Amy Tan, a Novel of Two Sisters, Two Worlds, and Few Ghosts.

At the beginning of their relationship, Kwan behaved really like the Chinese way of elder sister, but Olivia was quite the different kind of younger sister in the Chinese understanding. And Olivia said,

I was Kwan's wiling captive, and she was my protector. (p. 15)

When my teacher called Mom to say I was running a fever, it was Kwan who showed up at the nurse's office to take me home. When I fell while roller-skating, Kwan bandaged my elbows. She braded my hair. She packed lunches for Kevin, Tommy, and me. She tried to teach me to sit sing Chinese nursery songs. She soothed me when I lost a tooth. She ran the washcloth over my neck while I took my bath.

I should be grateful to Kwan. I could always depend on her. She liked nothing better than to be by myside. But instead, most of the time, I resented her for taking my mother's place. (p. 14) 
Even in front of the other playmates, Olivia shouted Kwan was not her sister and she hated her.

And the worst part was that Olivia had to share her bed with Kwan. In Olivia mind, Kwan pushed Chinese secrets into her brain and changed how she thought about the world. And she was even having nightmares in Chinese.

The description set the relations between the half-sisters. Kwan was necessary in the family, but she did too much for the kids. She did the duty of a mother to the kids of the family.

\section{The Psychological Critics}

The psychological analysis for the novel is obvious. The foundation of Freud's contribution to modern psychological emphasizes on the unconscious aspects of the human psyche. Freud changed our notions of human behavior by exploring new or controversial areas such as wish fulfillment, sexuality, the unconscious, and repression.

The unconscious comes into being when we are very young through the repression, the expunging from consciousness of these unhappy psychological events. However, repression does not eliminate our painful experiences and emotions (Lois, 1950, p. 13).

The whole novel is about the secret senses - that some of the senses are some unconsciousness bedded in the mind from the childhood. The whole story, especially the story or the memories by Kwan are her unhappy psychological events happening at China when she was young.

In the whole novel, the key word is the sense. With the indication of the senses, the author mentioned the sweet, sour, bitter, pungent, and salty in life, the overview of the world, such as the anger, respect, shame, hope, and stupidity. But the more important is how the girls can sense the existence of the ghosts. Ghosts are the powerful images in Chinese culture. With the psychological analysis, the ghosts are the subconscious images in the mind. The ghost is one of the senses in the novel. "It's not just grudges that I hang on to. I remember a girl on my bed. I remember Eric. I remember the power of inviolable love. In my memory, I still have a place where I keep all those ghosts" (p. 60).

\section{The Postcolonial Criticism}

As the novel The Hundred Secret Senses was written by Amy Tan, the novel was undoubtedly a postcolonial novel. Amy Tan wrote the characters in old China and in America. For the postcolonial criticism, the main focus is the identity value and the colonized people's understanding of their identity. That is, the colonized people were inferior to the colonial country people. The postcolonial critics examine the representation of other cultures in literature as a way of achieving this end. ${ }^{1}$

\section{The Identity of the People in America}

First of all, in the novel one of the half-sister Kwan was born in China and went to America when she was almost an adult. For her the identity is really a question. "Tell me, whom do I belong to? What country? What people? What family? That night, I lay my mat, thinking about those questions. What country? What people? What family?" (p. 165). That is the typical question for the postcolonial criticism. People who have the postcolonial experiences, might ask the questions of their identity.

\footnotetext{
${ }^{1}$ See http://www19.homepage.villanova.edu/silvia.nagyzekmi/colonial/barry_po-co\%20criticism.pdf.
} 
Identity is their big issue in the story for some time. Although both of sisters were wondering about their identity, they are different. For Kwan it is the society's recognition for her, and her position in the society, but for half-sister it is her own recognition among her relatives and friends first and a new identity in the society.

\section{The Inferiority of the People From the Colonialized Country}

On the other hand, the typical feature of the postcolonial critic is that the sisters in the novel are not equal in their social and family recognition. The American born sister is always superior to her half-sister who was born in China. This indicates the self-appreciation of the colonial people. What the half-sister does seems improper, stubborn, and not understandable. And sometimes the actions are queer and obscure.

But now Kwan has dropped by, uninvited, while I'm the middle of a phone call to the printer's I let her in, then return to my office. She's brought some homemade wontons, which she is storing in, my freezer, commenting loudly in the lack of provisions my fridge and cupboard... (p. 38)

And in the American born sister's mind, she confessed after she separated with her husband that,

I never call her out of the blue to say, how about going to dinner or a movie just the two of us, I never take any pleasure in simple being nice to her. Yet there she is, always hinting about our going together to Disney or Reno or China. ...I neglect the fact that Kwan merely wants to spend more time with me, that am her greatest joy. Oh, Go, does she hurt the way I do now? I'm not better than my mother! — carless about love. I can't believe how oblivious I've been to my won cruelty. (p. 172)

In front of the Westerners, Kwan felt she was small and dirty. It is the representative of the colonialized people in the face of the colonial people. For the colonial people, they have the superior in the mind and on the other hand the people from the colonial country they have no confidence for the country, for the situation and surrounding, and for the culture they have.

\section{The Urban and Rural China in the Late 20th Century}

As far as Said (1978) was concerned, the Orient is a fictional invention by the Westerners out of their ignorance, prejudice, curiosity about the Orient. As long as the Westerners are concerned that the Orient is either ugly, backward, dark, or mysterious, or exotic. Such stereotypes and hegemony are pervasive in the Amy Tan's novels. In her novel, China is depicted as vilified and feudal, violent and backward.

Looking up toward cloud level, we can see the amazing peaks, which resemble prehistoric shark's teeth, the clichéd subject of every Chinese calendar and scroll painting. But tucked in the guns of these ancient stone formations is the bright of high-rises, their stucco exteriors grimy with industrial pollution, their signboards splashed with garish red and gilt characters. Between these are lower building form an earlier era, all of them painted a proletarian toothpaste-green... (p. 172)

This is the impression Olivia and Simon have on China's most beautiful city. In this description, Amy neglected the modernization and civilization of Guilin, and she only noticed the pollution.

The previous description of Guilin and Changmian in the novel is not the real image of China, but an Orientalized one. The first vilifies China's most beautiful city, while the second beautifies the rural village. In Amy's mind, Guilin's ugliness embodies the Westerner's thought about the Orient. What they see is not the real China image.

\section{Kwan's Language Was the Repetitive of the Inferior From the Other}

In the novel, one of the main characters, Kwan's English was not only broken language; sometime her English was not correct. They are the inferior from the standard one. 
"That young police officer—come my house time my car get stolen?—last lifetime he missionary in China, always saying Amen, Amen” (p. 161).

From the previous sentence, we can see that Kwan used wrong past participle of the word "steal". It is the symbol of uneducated.

\section{Conclusion}

With the discussion above, the novel shows the multiple aspects of the Chinese-American culture conflicts, the mother and daughter relations, the psychological critics, and the postcolonial identity. The writer took the culture as the base of her writing. Women characters mostly dominate the stories that happened far and long in old China. Because she lives in America, and her stories are those she inevitably avoided the postcolonial trace in the story. Of course, the whole story is about the secret senses which are the main domain searching for some psychological problems in the characters mind. Just because she typical identity and the topic and the period, Amy Tan wrote it vividly and successfully.

\section{References}

Ellen, K. (1995). From Amy Tan, a novel of two sisters, two worlds, and few ghosts. Retrieved from http://www.doc88.com/p-9631902466821.html

Lois, T. (1950). Critical theory today. New York: Routledge Taylor \& Francis Group.

$\begin{array}{llll}\text { Postcolonial criticism. } & \text { (n.d.). Retrieved from }\end{array}$ http://www19.homepage.villanova.edu/silvia.nagyzekmi/colonial/barry_po-co\%20criticism.pdf

Said, E. (1978). Orientalism. New York: Pantheon.

Tan, A. (1995). The hundred secret senses. New York: Ivy Books. 